\title{
Terrorism, Death Anxiety and Anger; A Comparison of Police and Shopkeepers
}

\author{
Falak Niaz ${ }^{1}$ and Madiha Asghar ${ }^{2}$ \\ Islamia College Peshawar
}

The present study was designed to find the association between terrorism catastrophizing, death anxiety and anger among police and shopkeepers. The total sample comprised of two hundred and seventy six $(\mathrm{N}=276)$ subjects, including one hundred and thirty five $(\mathrm{n}=135)$ police personnel and one hundred and forty one $(\mathrm{n}=141)$ shopkeepers using convenient sampling technique. The age range was 24 to 60 years. Terrorism catastrophizing scale, death anxiety scale, and Novaco anger scale were used for data collection. Both groups were individually interviewed and were contacted through proper channel. Association between terrorism catastrophizing, death anxiety and anger was investigated among police personnel and shopkeepers. Comparison was made between police personnel and shopkeepers regarding terrorism catastrophizing, death anxiety and anger. Results revealed that there was no significant difference between the scores of shopkeepers and police personnel on terrorism catastrophizing and anger, however police personnel showed slightly higher scores on death anxiety as compared to shopkeepers. Simple linear regression of the data revealed terrorism catasrophizing as a predictor of death anxiety among police personnel and shopkeepers. Significant negative association between anger and terrorism catastrophizing among police personnel predicts controlled fear at the time of crises and steadfastness in fighting spirit. Findings suggests that police is as vulnerable to consequences of traumatic events as any other individual or professional, yet police of Khyber Pakhtunkhwa is determined in taking risks as shown in negative association between anger and terrorism catestrophizing.

Keywords. Terrorism catastrophizing, anger, death anxiety, police and shopkeepers

Terrorism is a global issue and kind of psychological warfare. The mechanism of action to terrorize the society may be different but

\footnotetext{
${ }^{1}$ MS Scholar, Department of Psychology, Islamia College Peshawar

${ }^{2}$ Assistant Professor, Department of Psychology, Islamia College Peshawar
} 
their purpose remains the same. The mechanism could be in the form of blasts, suicide bombing, bio-terrorism, narco-terrorism and financial terrorism. Islamic Republic of Pakistan has been facing terrorism in variety of forms for the last 15 years. Most of the terrorist's attacks in Pakistan took place in the workplaces where people work because in international terrorism corporation or workplaces are regarded as high value targets (Fullerton et al., 2003; Ursano et al., 2004b; Vineburgh, 2004). Most of the areas attacked in Pakistan have been public areas such as bazars, in which a number of people lost their lives and many were injured. The terrorists attack two types of people they include common citizens in the target area and targeted groups particularly include staff of the law enforcement agencies such as police, because they are entrusted with responsibility to ensure peace. Anderson (2002) said that of all the occupations, law enforcement is physically and emotionally threatening and challenging jobs. Police personnel on regular basis face number of threatening events and are targeted by the terrorists in Khyber Pakhtunkhwa.

According to Southern Association for Institutional Research (2010) Pakistan has been a dwelling of mortalities that expanded expressively since 2003 however the year 2009 might be called as the deadly year in its history, with at least 11,585 mortalities in a year. The year 2009 documented a total of 76 suicide attacks, in which 949 cleared people were murdered. Similarly in the year 2010, over-all 34 explosive blasts were witnessed, murdered 775 people and 1359 wounded (South Asia Terrorism Portal, 2010).

The negative impact of terrorism on nation's mental health, infrastructure, national economy and communities created by workplace disruption is one of the major aims of the terrorism (Ursano et al., 2004b, Schouten et al., 2004). Terrorism is the extreme form of violence in workplace (Bowie et al., 2005).

Terrorism is defined in minimum of four distinguished features. First and leading, terrorism is violence for political effect (Sandler, 2005). Second, terrorism is "a strategic and planned act" (Hoffman, 1998). Third, terrorists are not guaranteed by established rules of warfare or codes of conduct and, fourth, terrorism is "designed to have broad psychological consequences".

The US State Department defined terrorism as extended to include not only actual violence directed at civilian targets, but also its threat. Terrorists, in short, seek to achieve their goals, disturbing routine activities of people and also producing uncertainty between normal people, deliberately creating "immense terror" (Cooper, 2001).

People of Pakistan in general and Khyber Pakhtunkhwa specifically are faced with the challenges of terrorist events in one or 
some other forms, such events and occurrences have been increasing like cancer in Pakistan, there has been a steady enlargement in terrorist events since 2006 with its highest in august, 2007 and 2009 (South Asia Terrorism Portal, 2010). Khyber Pukhtunkhwa and FATA have been one of the most affected areas by the terrorist attacks so are the law enforcement agencies of Khyber Pakhtunkhwa as the main target of suicidal attacks (Yousafzai \& Siddiqui, 2007). Such attacks badly afflicted the people of Khyber Pakhtunkhwa psychologically (Ahmad et al., 2013)

The study of Cottraux (2004) showed that anxious and unrealistic apprehension is outcome of cognitive distortions, which further develop and predict psychological problems. The phenomenon, which is described by the model of catastrophizing, it is supposed that the major incident like $9 / 11$ produced an extreme death worry that extremely fluctuations people views about safety and security (Sinclair \& LoCicero, 2007).

Apprehension of future terrorist attacks is extremely distressing in expressions of mental functioning; there are more literature, widespread research and surveying evidence (Kramer, et al., 2004) on fear of future terrorism among people living in terrorism affected areas. A research showed that fear of future terrorism proved to be a major cause of behavioral problems, developing worry, sadness, physical stress and fear of death among victims of terror events (Sinclair \& Lo Cicero, 2007).

Exposure to terrorist attacks knowingly related to more harm of psychosocial resources and develops post-traumatic stress disorder (PTSD) and depression (Hobfoll, et al., 2006). Similarly Verger et al., (2004) assessed more occurrence of post-traumatic stress disorder. The study of Pfefferbaum et al. (2005) demonstrated that terrorist attacks produce fear, anxiety, crying behavior, whimpering, fear of darkness, confusion, depression, night mares, irritability, fear of loneliness, sleep disruption and use of medication etc.

According to Greenberg et al (2004) death is the biggest danger as well as the greatest challenge to humankind. This affects everyone in many ways more than we care to know because of the human being potentials which enable us to form a social structure; death has developed into a very complex and different system, including physical, mental, spiritual, general, and cultural components (Kastenbaum, 2000). Terror Management Theory is inspiring in describing situation of clarifying that how people respond and feel under the bad terrorist incidents (Pyszczynski, Solomon, \& Greenberg, 2003).

Anger is a strategy for handling with congested goals and experienced bad incidents (Cox et al., 1999; Stein \& Levine, 1989). 
People who are regularly or uncertainly angry are often unable to handle stressful life events appropriately and become frustrated, which leads to increased anger (Cox et al., 1999). Furthermore, recent research showed that people with chronic aggressive behavior have poor social interactions with others (Monnier et al,. 1998). Persistent and prolonged anger affects our daily life routine, physical and mental health, and cause frustration. Such type of anger is harmful for themselves and for others belonging to them or around them. It may cause impairment in their relationship and daily routine activities, one would not be able to establish good relationships and continue healthy routine activities. The study conducted by Smith et al., (2001) explained that American people reported more irritated, anxious and embarrassed in the weeks following the $9 / 11$ attacks.

Positive and negative feelings can co-happen (Cassese and Weber 2011). Neuro-scientific examination has demonstrated that these optimistic and bad feelings influence decision making (Damasio 1994; Marcus et al. 2000; Valentino et al. 2011; Cassese and Weber 2011). Specifically, negative feelings like fear lead to attempt to keep away from mischief and threat while positive feelings enabling an individual to face the threatening situation (Gray 1990; Cacioppo et al. 1999; Huddy et al. 2007).

Fear and anger may lead drive one to take part in several types of risk taking decisions. While most versions of affective intelligence theory argue that both feelings produce the surveillance system (Marcus et al. 2000), later research shows that the impacts of fear and anger may contrast, fear prompts issue centered data looking for danger opposed conduct and expanded watchfulness, while anger builds danger looking for conduct and the inspiration to take part in secretarial activity (Lerner and Keltner 2000, 2001; Carver and Harmon-Jones 2009; Valentino et al. 2009, 2011; Brader et al).

The fear and anger originate from cognitive appraisal theories of emotions (Smith and Ellsworth 1985; Lazarus 1991; Smith et al. 2008; Carver and Harmon-Jones 2009; Cassese and Weber 2011; Valentino et al. 2011). These speculations propose that our enthusiastic reactions emerge as a result of how we comprehend and decipher the circumstance we encounter. In light of the fact that individuals regularly evaluate the same circumstance in an unexpected way, cognitive appraisal theory explains why individuals encountering the same marvels or occasion may show diverse feelings of the same valence. The center of such speculations is the subjective examinations that produce specific emotions. Whether a threat leads to fear or to anger therefore depends on how a threat is professed and measured (Krueger (2011).

Peshawar Journal of Psychology and Behavioral Sciences, 2015, Vol. 1, No. 1, 85-98 
Terrorism is a serious social issue in Pakistan that causes psychological distress and problems. The aim of this study was to assess terrorism catastrophizing, death anxiety and anger among police personnel and shopkeepers. Police personnel and people working in markets of Peshawar are directly confronted with terrorist attacks, as they are frontline workers.

The present study was designed to assess association between life threating events such as bomb blasts, suicide attacks and target killing on terrorism catastrophizing, anger and death anxiety among front line fighters i.e. police and people belonging to busy workplace areas i.e. shopkeepers.

\section{Objectives}

The research objectives of this study are as follow:

1. To investigate terrorism catastrophizing, anger and death anxiety among police personnel and shopkeepers

2. To find the association between terrorism Catastrophizing with anger, and death anxiety among police personnel and shopkeepers

\section{Hypotheses}

1. Terrorism catastrophizing predicts death anxiety

2. Higher the anger, lower will be terrorism catastophizing

\section{Sample}

\section{Method}

Total sample comprised of two hundred and seventy six $(\mathrm{N}=276)$ subjects, including one hundred and thirty five $(\mathrm{n}=135)$ police personnel (non-officer rank) and one hundred and forty one $(n=141)$ shopkeepers. The age range was 24 years to 60 years olds. Convenient sampling technique was used for data collection. Data from the shopkeepers was collected from different main markets of district Peshawar, i.e., Khyber bazar, Mena bazar, Gunj Gate bazars, Qaisa Khawani, Firdous, Ashraf Road, Danish Abad, Nasir Bagh \& Board bazar while the data from police personnel including police constables was collected from different police stations, i.e., Police Station university of Peshawar, Town, Tehkal, Regi, Gulbahar, Sadar, Hayatabad, Kabuli, Faqirabad, Pishtakhara police station and police line of district Peshawar. 
Table 1

Demographic Information of Police Personnel and Shopkeepers $(\mathrm{N}=276)$

\begin{tabular}{|c|c|c|c|}
\hline Variables & $\begin{array}{l}\text { Police } \\
\mathrm{n}(\%)\end{array}$ & $\begin{array}{c}\text { Shopkeepers } \\
\text { n (\%) }\end{array}$ & $\chi^{2}$ \\
\hline \multicolumn{4}{|l|}{ Age } \\
\hline $24-30$ years & 66(48.9) & $56(39.7)$ & \multirow{3}{*}{$13.270^{* *}$} \\
\hline $31-40$ years & $50(37.0)$ & $39(27.7)$ & \\
\hline $41-60$ years & 19(14.10) & $46(32.6)$ & \\
\hline \multicolumn{4}{|l|}{ Education } \\
\hline \multirow{2}{*}{\multicolumn{4}{|c|}{$0-10$ years }} \\
\hline & & & \\
\hline 12-14years & $53(39.26)$ & $56(39.72)$ & \multirow[t]{2}{*}{$44.418^{* * *}$} \\
\hline$>16$ years & $6(4.4)$ & $5(3.56)$ & \\
\hline \multicolumn{4}{|l|}{ Marital status } \\
\hline Married & $93(68.9)$ & $98(69.5)$ & \multirow[t]{2}{*}{.912} \\
\hline Unmarried & $42(31.1)$ & $43(30.5)$ & \\
\hline \multicolumn{4}{|c|}{ Socioeconomic Status } \\
\hline Lower class & $1(0.75)$ & $14(9.93)$ & \multirow{3}{*}{$21.296 * * *$} \\
\hline Middle class & 134(99.26) & $1 z s 18(83.69)$ & \\
\hline Upper class & 0 & $9(6.39)$ & \\
\hline
\end{tabular}

Table 1 shows comparison of demographic variables between police personnel and shopkeepers. The result of the chi-square on demographic variables of police personal and shopkeepers shows a significant difference at $\mathrm{p}<0.001$ level on education, and socioeconomic status and there was no significant difference on marital status between shopkeepers and police personnel.

\section{Tools}

\section{Terrorism Catastrophizing Scale}

Terrorism catastrophizing was a 13 items scale (Sinclair \& LoCicero, 2007) comprised of three subscales, i.e., helplessness, magnification $\&$ ruminations. Terrorism catastrophizing was a five point Likert Scale, ranging from strongly agree to strongly disagree with a range of 13 to 65 and a cut-off score of 33 .

\section{Death Anxiety Scale}

The Death Anxiety Scale developed by Kouser (2002) contained 20 items with five point ratings, 1 for Strongly Agree and 5 for Strongly 
Disagree. The possible score range was 20 to 100 . The alpha coefficient reliability of the scale is 0.95 .

\section{Novaco Inventory}

Novaco Anger Scale was developed by Novaco (1975). NAS consisted of 25 items, measuring anger among adults.

\section{Procedure}

After seeking approval from officials of Police Department, and prior appointment from police personnel of different police stations and shopkeepers of different main markets of district Peshawar commercial areas, Khyber Pakhtunkhwa, were individually contacted for the purpose of data collection. Before initiating formal administration of scales the aim of the research was briefly explained to each participant of the study. After establishing rapport a set of questionnaires was handed over to the participants individually, comprising of demographic sheet and questionnaires of the study. They were requested to respond honestly and fairly.

\section{Results}

Table 2

Alpha Reliability Co-efficient of Scales $(N=276)$

\begin{tabular}{|c|c|c|c|c|c|c|c|}
\hline \multirow{2}{*}{ Scales } & \multirow{2}{*}{$\begin{array}{l}\text { No of } \\
\text { items }\end{array}$} & \multirow{2}{*}{$M$} & \multirow{2}{*}{$S D$} & \multirow{2}{*}{$\alpha$} & \multicolumn{2}{|c|}{ Ranges } & \multirow{2}{*}{ Skew } \\
\hline & & & & & Actual & Potential & \\
\hline TCS & 13 & 36.72 & 6.10 & .63 & $(13-65)$ & $(20-55)$ & .171 \\
\hline Rum & 5 & 13.71 & 3.06 & .57 & $(5-25)$ & $(3-15)$ & .249 \\
\hline Mag & 3 & 8.05 & 2.49 & .53 & $(3-15)$ & $(3-15)$ & .200 \\
\hline Help & 5 & 14.96 & 2.66 & .08 & $(5-25)$ & $(7-23)$ & -.133 \\
\hline DAS & 20 & 56.18 & 12.75 & .89 & $(20-100)$ & $(28-95)$ & .092 \\
\hline NAS & 25 & 57.05 & 17.35 & .96 & $(25-100)$ & $(20-96)$ & .079 \\
\hline
\end{tabular}

Table 3

Inter Scale Correlation $(N=276)$

\begin{tabular}{clcccccc}
\hline & Scales & 1 & 2 & 3 & 4 & 5 & 6 \\
\hline 1 & TCS & - & & & & & \\
2 & Rum & $.73^{* *}$ & - & & & & \\
\hline
\end{tabular}

Peshawar Journal of Psychology and Behavioral Sciences, 2015, Vol. 1, No. 1, 85-9 


\begin{tabular}{lllllllll}
\hline 3 & Mag & $.68^{* *}$ & $.30^{* *}$ & - & & & \\
4 & Help & $.70^{* *}$ & $.37^{* *}$ & $.18^{* *}$ & - & & \\
5 & DAS & $.17^{* *}$ & .07 & $.22^{* *}$ & .07 & - & \\
6 & NAS & $-.14^{*}$ & -.10 & $-.13^{*}$ & -.07 & .09 & - \\
\hline
\end{tabular}

Note. $T C S=$ Terrorism Catastrophizing Scale; Rum $=$ Rumination Subscale; Mag $=$ Magnification Subscale; Help = Helplessness Subscale; DAS = Death Anxiety Scale; $N A S=$ Novaco Anger Scale. ${ }^{*}=p<0.05, * *=p<0.01, * * *=p<.001$.

Table 3 shows that terrorism catastrophizing has significant positive correlation with death anxiety, and negative correlation with anger.

Table 4

Association between Death Anxiety and Terrorism among Police Personnel and Shopkeepers $(\mathrm{N}=276)$

\begin{tabular}{|c|c|c|c|c|c|c|}
\hline \multirow[t]{2}{*}{ Variables } & \multicolumn{3}{|c|}{$\begin{array}{l}\text { Police Personnel } \\
\quad(\mathrm{N}=135)\end{array}$} & \multicolumn{3}{|c|}{$\begin{array}{l}\text { Shopkeepers } \\
(\mathrm{N}=141)\end{array}$} \\
\hline & B & SE(B) & $\beta$ & B & SE(B) & $\beta$ \\
\hline $\begin{array}{l}\text { Death } \\
\text { Anxiety }\end{array}$ & $\begin{array}{c}.295 \\
{[-031, .621]}\end{array}$ & .165 & $.153^{*}$ & $\begin{array}{c}.447 \\
{[.101, .793]}\end{array}$ & .175 & $.212 * *$ \\
\hline
\end{tabular}

Table 4 shows significant simple linear regression predicting death anxiety in shopkeepers based on terrorism catastrophizing. The results of shopkeepers indicate $\left(\mathrm{F}(1,139)=6.527, \mathrm{P}<.0 .01\right.$, with an $\mathrm{R}^{2}$ of .045. The participants predicted $36.608+.447$. Whereas the linear regression between death anxiety based on terrorism catastrophizing in police personnel is significant at $\mathrm{p}<0.05$.

Table 5

Multiple Regression Analysis of Sub-Scales of Terrorism Catastrophizing Predicting Death Anxiety among Police Personnel and Shopkeepers $(\mathrm{N}=276)$

\begin{tabular}{llllllll}
\hline & \multicolumn{3}{c}{$\begin{array}{c}\text { Police Personnel } \\
(\mathrm{N}=135)\end{array}$} & & \multicolumn{3}{c}{$\begin{array}{c}\text { Shopkeepers } \\
(\mathrm{N}=141)\end{array}$} \\
\cline { 2 - 3 } \cline { 6 - 8 } Variables & $\mathrm{B}$ & $\mathrm{SE}(\mathrm{B})$ & $\beta$ & & $\mathrm{B}$ & $\mathrm{SE}(\mathrm{B})$ & $\beta$ \\
\hline Constant & 52.81 & 6.23 & & & 37.64 & 6.80 & \\
Rum & .64 & .48 & .12 & & -.31 & .67 & -.05 \\
Mag & .55 & .39 & .12 & & 1.29 & .49 & $.23^{* *}$ \\
Help & -.21 & .37 & -.05 & & .53 & .48 & .11 \\
\hline
\end{tabular}

Peshawar Journal of Psychology and Behavioral Sciences, 2015, Vol. 1, No. 1, 85-98 


\begin{tabular}{|c|c|c|}
\hline $\mathrm{R}^{2}$ & .038 & .068 \\
\hline $\mathrm{F}$ & 1.72 & $3.34 *$ \\
\hline
\end{tabular}

Table 5 shows Sub-scales of terrorism Catastrophizing as predictor of death anxiety among police personnel and shopkeepers. Analysis shows that there is no significant regression equation between Sub-scales of terrorism Catastrophizing as predictor of death anxiety among police personnel and shopkeepers. The table is statistically not significant at $\mathrm{p}<.867$ with variance $\mathrm{R}^{2}$ of .038 and adjusted $\mathrm{R}^{2}$ is -.007 .

Table 6

Mean Difference and t-Value of Police Personnel and Shopkeepers on Major Variables of the Study ( $\mathrm{N}=276)$

\begin{tabular}{|c|c|c|c|c|c|c|c|c|c|}
\hline \multirow[b]{2}{*}{ Variables } & \multicolumn{2}{|c|}{$\begin{array}{l}\text { Police } \\
(135)\end{array}$} & \multicolumn{2}{|c|}{$\begin{array}{c}\text { Shopkeepers } \\
\text { (141) }\end{array}$} & \multirow[b]{2}{*}{$\mathrm{t}(274)$} & \multirow[b]{2}{*}{ Sig } & \multicolumn{2}{|c|}{$95 \% \mathrm{CI}$} & \multirow{2}{*}{$\begin{array}{c}\text { Cohan } \\
\text { d }\end{array}$} \\
\hline & M & SD & $\mathrm{M}$ & SD & & & ower & Upper & \\
\hline TCS & 36.52 & 5.90 & 6.91 & 6.30 & -.52 & .59 & & 1. & 0.06 \\
\hline & & & 48 & & & .02 & U5 & & 0.26 \\
\hline Mag & 8.32 & 2.58 & 7.79 & 2.38 & 1.77 & .07 & -1.03 & -.06 & 0.04 \\
\hline Help & 14.97 & 2.70 & 14.95 & 2.62 & .062 & .95 & -.05 & 1.12 & 0.007 \\
\hline Ang & 57.88 & 16.13 & 56.26 & 18.46 & .77 & .43 & -.2 .49 & 5.73 & 0.09 \\
\hline DAS & 59.39 & 11.35 & 53.11 & 13.29 & 4.21 & .001 & 3.34 & 9.21 & 0.50 \\
\hline
\end{tabular}

Note. ${ }^{*}=p<0.05,{ }^{* *}=p<0.01,{ }^{* * *}=p<.001 . T C S=$ Terrorism Catastrophizing Scale; Rum $=$ Rumination $;$ Mag = Magnification; Help $=$ Helplessness; DAS $=$ Death Anxiety Scale. ${ }^{*}=p<0.05, * *=p<0.01, * * *=p<.001$.

Table 6 shows results non-significant results except for death anxiety. Police personnel scored significantly higher on death anxiety as compared to shopkeepers. There is a moderate effect size i.e 0.05 on scores of death anxiety between police personnel and shopkeepers.

Table 7

Association between Terrorism and Anger among Police Personnel and Shopkeepers $(N=276)$

\begin{tabular}{|c|c|c|c|c|c|c|}
\hline \multirow[t]{2}{*}{ Variables } & \multicolumn{3}{|c|}{$\begin{array}{c}\text { Police Personnel } \\
(\mathrm{N}=135)\end{array}$} & \multicolumn{3}{|c|}{$\begin{array}{l}\text { Shopkeepers } \\
(\mathrm{N}=141)\end{array}$} \\
\hline & B & SE(B) & $\beta$ & B & SE(B) & B \\
\hline $\mathrm{TC}$ & $\begin{array}{l}-.104 \\
{[-.165,-.044]}\end{array}$ & .30 & $\begin{array}{l}- \\
.286^{* *}\end{array}$ & $\begin{array}{l}-.013 \\
{[-.070, .044]}\end{array}$ & .029 & -.038 \\
\hline
\end{tabular}

Note. $*=p<0.05, * *=p<0.01, * * *=p<.001$.

Table 7 shows significant simple linear regression predicting negative association between terrorism catastrophizing and anger in police personnel at $\mathrm{p}<0.01$. The results of the police personnel indicates 
$\left(\mathrm{F}(1,133)=11.806, \mathrm{P}<0.01\right.$, with $\mathrm{R}^{2}$ of .082 . and participants predicted $(42.563)+(-.104)$. Whereas linear regression between terrorism catastrophizing based on anger is not statistically significant in shopkeepers.

Table 8

Multiple Regression Analysis of Sub-Scales of Terrorism Catastrophizing Predicting Anger among Police Personnel and Shopkeepers $(\mathrm{N}=276)$

\begin{tabular}{llllllll}
\hline & \multicolumn{3}{c}{$\begin{array}{c}\text { Police Personnel } \\
(\mathrm{N}=135)\end{array}$} & & \multicolumn{3}{c}{$\begin{array}{c}\text { Shopkeepers } \\
(\mathrm{N}=141)\end{array}$} \\
\cline { 2 - 3 } \cline { 6 - 7 } Variables & $\mathrm{B}$ & $\mathrm{SE}(\mathrm{B})$ & $\mathrm{B}$ & & $\mathrm{B}$ & $\mathrm{SE}(\mathrm{B})$ & $\beta$ \\
\hline Constant & 86.49 & 8.61 & & & 57.11 & 9.75 & \\
Rum & -.54 & .67 & -.073 & & -.35 & .96 & -.03 \\
Mag & -1.26 & $.54 *$ & -.20 & & -.47 & .70 & -.06 \\
Help & -.92 & .51 & -.15 & & .39 & .69 & .05 \\
$\mathrm{R}^{2}$ & .091 & & & & .006 & & \\
$\mathrm{~F}$ & $4.39^{* *}$ & & & & .27 & & \\
\hline
\end{tabular}

Note. $*=p<0.05, * *=p<0.01, * * *=p<.001$. Rum = Rumination; Mag = Magnification; Help $=$ Helplessness

Table 8 shows sub scales of terrorism Catastrophizing as a negative predictor of anger among police personnel. Police personnel show slightly significant association between magnification and anger. The negative association between terrorism related future fear and anger predicts quality of training of the police personnel.

\section{Discussion}

Terrorism is a global issue and kind of psychological warfare. The mechanism of action to terrorize the society may be different but their purpose remains the same. The mechanism could be in the form of blasts, suicide bombing, bio-terrorism, narco-terrorism and financial terrorism. Republic of Pakistan has been facing terrorism in variety of forms for the last 15 years. According to Southern Association for Institutional Research (2010) Pakistan has been a dwelling of mortalities that enlarged expressively since 2003 but the years 2009 might be called the deadly year in its history, with at least 11,585 mortalities in a year. The year 2009 documented a total of 76 suicide attacks, in which 949 cleared people were murdered. Similarly in the year 2010, over-all 34 explosive blasts were witnessed, murdered 775 people and 1359 wounded (South Asia Terrorism Portal, 2010). The front line relief 
workers and security providers even the victims of attack are police and main markets at different places of Pakistan, particularly Khyber Pakhtunkhwa.

Suicide attacks, and other such events and occurrences had been increasing and spreading like cancer in Pakistan, there had been a steady enlargement in terrorist events since 2006 with its highest in august, 2007. Khyber Pukhtunkhwa and FATA were the most affected by the terrorist attacks and the law enforcement agencies were the main target of suicidal attacks (Yousafzai \& Siddiqui, 2007). Such attacks badly afflicted the Pakistani nation.

The study of Cottraux (2004) found that anxious and unrealistic apprehension is outcome of cognitive distortions, which further develop and predict psychological problems. The phenomenon, which is described by the model of catastrophizing, it is supposed that the major incident like 9/11 produced an extreme death worry that extremely distorted people's views about safety and security (Sinclair \& LoCicero, 2007).

According to the first hypothesis of the present study that terrorism catastrophizing predicts death anxiety. The findings revealed that shopkeepers of main busy markets of district Peshawar had shown high level of association between terrorism related future fear and death anxiety as compared to police personnel. Police personnel showed lower association between death anxiety and terrorism catastrophizing. The shopkeepers are more vulnerable and are more prone to the negative consequences of terrorism catastrophizing as compared to police personnel.

Anger is a normal emotional reaction to certain stressful situation. It is commonly assumed that terrorism and terrorist's related events might cause high level of anger among the victims or the dwellers of the effected area. With this assumption it was hypothesized that terrorism related fear might have effect on the level of anger among police personnel and shopkeepers. The findings of the preset study revealed that police personnel of district Peshawar have shown significant negative association between terrorism catastrophizing and anger. The findings indicated higher the level of terrorism catastrophizing lower will be the anger among police personnel whereas there was no significant association between anger and terrorism catastrophizing. According to Lerner \& Keltner (2000) risk perception of the individual is predicted by anger and fear oppositely. Such as fearful people expressed negative risk estimates and risk-averse choices, angry people expressed positive risk estimates and risk-seeking choices. The significant negative association between terrorism catastrophizing and anger among police personnel of district Peshawar indicated that they 
were more optimistic and ready for risk-seeking choices, which supported the previous studies.

\section{Conclusion}

It is concluded from the findings of the present study that shopkeepers have shown significant association between terrorism catasrohizing and death anxiety and no significant association between anger and terrorism catastrophizing as compared to police personnel of district Peshawar. The terrorism catastrophizing not only affected the mental health of human beings but also affect their daily routine functioning. The police personnel and shopkeepers both need professional care to build and enhance their capacity to effectively cope with stressful situations. Adequate psychological counseling centers have to be established in all government health centers. Awareness raising education programs are required to be launched by government authorities to address the consequences of terrorism with the help of various formal and informal techniques, such as workshops, seminars, long term and short-term trainings. Training must include communication skills particularly "anger management techniques" and "expression of anger" so that healthy communication may prevail between police and public. Careful use of media such as talk shows, awareness campaigns and producing quality dramas to reflect the challenges associated with trauma and effect of terrorism upon police personnel with solutions and awareness among general public for promoting mental health and reducing the gap of understanding between police and general public.

\section{Limitations}

- In this study large sample and Probability sampling technique could not be possible due to short time period.

- Descriptive Cross-sectional research design was used to find association between terrorism, death anxiety, and anger.

- Only male shopkeepers and police constables were included in the study.

\section{Recommendations}

- Large sample should be participated from the Police Department.

- Participants from other law enforcement agencies should be included as they also the front line workers and most vulnerable to terrorism. 
- Other variables can be taken with terrorism catastrophizing like religiosity, spirituality, PTSD, emotional intelligence, Intolerance, self-esteem, resilience, and job performance etc.

- Equal participation and gender balance should be taken to assess equally the impact of terrorism through terrorism catastrophizing among males and females.

\section{References}

Ahmad, K., Hussain, H., Khan, H.M., Zia-ur-Rehman., Naeemullah., Wahid, I., Kibria, Z., Ali, S. (2013). Frequency of post traumatic stress disorder and depression in people of Khyber Pakhtunkhwa due to terrorism. Journal of Saidu Medical College, 3(2) page 373378.

Carver, C. S. (1997). you want to measure coping but your protocol's too long: Consider the Brief COPE. International Journal of Behavioral Medicine, 4, 92-100

Cooper, H.H.A. (2001). Terrorism: The problem of definition revisited. American Behavioral Scientist, 44(6), 881-893.

Fullerton, C. S., Ursano, R. J., \& Norwood, A. E. (2003). Workplace interven- tions following trauma: A review of Interventions to Prevent or Treat Psycho- logical and Behavioral Consequences of Occupational or Workplace Exposure to Mass Traumatic Events. Final Report to NIOSH, Uniformed Services University, Bethesda, MD.

Hobfoll, S, E., Canetti-Nisim., Johnson, A., \& Robert, J. (2006). Exposure to terrorism, stress- related mental health symptoms, and defensive coping among Jews and Arabs in Israel. Journal of Consulting and Clinical Psychology, 74(2), 207-218.

Hoffman, B. (1998). Inside terrorism. New York: Columbia University Press.

Kouser, F. (2002). Death anxiety scale. National Institute of Psychology, Quiad-e- Azam University, Islamabad

Lerner, J. S., \&Keltner, D. (2001). Fear, anger, and risk. Journal of Personality and Social Psychology, 81, 146-159.

Lerner, J. S., Gonzalez, R. M., Small, D. A., \&Fischhoff, B. (2003). Effectsof fear and anger on perceived risks of terrorism: A national field experiment. Psychological Science, 14, 144-150.

Novaco, R. W (1975). The Novaco anger Inventory- Short Form (NAI25). Mental Health America of Northern Kentucky \& Southwest Ohio.

Novaco, R.W. (1975). Anger control: The development of an experimental treatment. Lexington, KY: Lexington. 
Pfefferbaum, B. J., Devoe, E. R., Stuber, J., Schiff, M., Klein, P. K, \& Fairbrother, G. (2005). Psychological impact of Terrorism on children and families in the United States.Journal of Aggression, Maltreatment and Trauma, 9(3-4), 305-317.

Pyszczynski, T., Solomon, S" \& Greenberg, J. (2003). In the wake of 91/1: The psychology of terror. Washington, DC: American Psychological Association.

Schouten, R., Callahan, M. V., \& Bryant, S. (2004). Community response to disaster: Th e role of the Workplace. Harvard Review of Psychiatry. 12(4), 229-237.

Smith, C. A., \& Ellsworth, P. C. (1985). Patterns of cognitive appraisal in emotion. Journal of Personality and Social Psychology, 48, 813-838

Southern Association for Institutional Research. (2010). Fidayeen (Suicide Squad) Attacks in Pakistan. Retricved November13, 2009, from http://www.satp.org/satporgtp/count ries/pakistan/database/Fidayeenattack.htm

Ursano, R. J., Vineburgh, N. T., \& Fullerton, C. S. (2004b). Corporate Health and Preparedness: bioterrorism preparedness. Presented at e Imperative for a Public Private partnership: Sam Nunn Bank of America Policy Forum, Atlanta, Georgia.

Valentino, N. A., Brader, T., Groenendyk, E. W., Gregorowicz, K., \& Hutchings, V. (2011). Election night's alright for fighting: The role of emotions in political participation. Journal of Politics, 73(1), 156-170.

Vineburgh, N. T. (2004). e Power of the Pink Ribbon: raising awareness of the mental health implications of terrorism. Psychiatry, 67(2), 137-146. 